\title{
Chemical variation of tannins and triterpenes in Brazilian populations of Maytenus ilicifolia Mart. Ex Reiss
}

\author{
Mossi, AJ.*, Mazutti, M., Paroul, N., Corazza, ML., \\ Dariva, C., Cansian, RL. and Oliveira, JV. \\ Departamento de Biologia, Universidade Regional Integrada - URI, \\ Av. 7 de Setembro, 1621, Campus de Erechim, CEP 99700-000, Erechim, RS, Brazil \\ *e-mail: amossi@uricer.edu.br
}

Received April 10, 2007 - Accepted July 30, 2007 - Distributed May 31, 2009

(With 3 figures)

\begin{abstract}
Maytenus ilicifolia and Maytenus aquifolia species are widely used as a cicatrisation agent, an anti-spasmodic, contraceptive, antiulcerogenic, diuretic and analgesic. Considering the importance of these species in popular medicine, this work is focused on the determination of the chemical content of tannins and the triterpenes friedelan-3-one, friedelan-3-ol and friedelin in 15 native populations of Maytenus ilicifolia distributed in the south and mind-west regions of Brazil. Correlation of the concentration of these compounds with the environmental parameters such as average annual temperature, climate, vegetation, geomorphology, latitude and altitude was determined using Pearson's coefficient. Results showed that average annual temperature and climate have significant effect on tannin content at a 95\% confidence level. The highest tannin concentration was found in Ponta Porã population, and for the triterpenes investigated, a significant correlation between their concentrations with the environmental variables studied was not verified.
\end{abstract}

Keywords: Maytenus, chemical variability, supercritical extraction.

\section{Variabilidade química de taninos e triterpenos em diferentes populações naturais de Maytenus ilicifolia Mart. Ex Reiss}

\begin{abstract}
Resumo
As espécies de Maytenus ilicifolia e Maytenus aquifolia são utilizadas como antiespasmódico, contraceptivo, antiulcerogênico, diurético, cicatrizante e analgésico. A ação antiulcerogênica dos extratos de Maytenus ilicifolia possuem relação com a presença de taninos e com os triterpenos friedelan-3-ona, friedelan-3-ol e friedelin. Este trabalho está focado na determinação do teor de taninos e dos triterpenos friedelan-3-ona, friedelan-3-ol e friedelin em 15 populações nativas de Maytenus ilicifolia distribuídas nas regiões Sul e Centro-Oeste do Brasil. A correlação entre a concentração destes compostos com variáveis ambientais, tais como temperatura média anual (TMA), clima segundo Koeppen, vegetação, geomorfologia, latitude e altitude foi determinada através do emprego da correlação de Pearson. Os resultados mostraram que as variáveis temperatura média anual e clima apresentaram influência significativa ao nível de confiança de $95 \%$ sobre a concentração de taninos. O maior teor de taninos foi encontrado na população de Ponta Porã, a qual possui uma temperatura média anual de $23{ }^{\circ} \mathrm{C}$. Para os triterpenos estudados, friedelan-3-ona, friedelan-3-ol e friedelin, não foi evidenciada correlação significativa entre a concentração destes compostos com as variáveis ambientais estudadas.
\end{abstract}

Palavras-chave: Maytenus, variabilidade química, extração em fluido supercrítico.

\section{Introduction}

The use of plants with pharmaceutical properties has received increased interest nowadays from both homeopathic and allopathic branches. These medicinal plants play an important role in public health, especially in developing countries, where it is believed that the intense

utilisation of plants with therapeutic action does not lead to intoxication.

In the Brazilian flora, there exists around 40,000 to 60,000 different kinds of vegetable species, and among them, Maytenus ilicifolia Mart. ex Reiss 1861 
(Celastraceae) is a native plant from the Atlantic forest, known as "espinheira-santa", "cancerosa" and also "cancarosa", among others (Jorge et al., 2004).

Maytenus ilicifolia and Maytenus aquifolia Mart. 1841 species are commonly used in popular medicine due to the attributed anti-spasmodic, contraceptive, antiulcerogenic, diuretic, cicatrisation and analgesic properties (Ohsaki et al., 2004; Vilegas et al., 1995; Tahir et al., 1999; Queiroga et al., 2000). The antiulcerogenic activity of buffered aqueous extracts of Maytenus ilicifolia and Maytenus aquifolia has been confirmed in laboratory tests (Souza-Formigori and Oliveira, 1991; Oliveira et al., 1991).

The presence of phenolic metabolites, such as tannins, flavonoids (Jorge et al., 2004; Radomski, 2004) and triterpenes (Queiroga et al., 2000; Mossi et al., 2004; Vilegas et al., 1995), could explain the use of some Maytenus species as anti-inflammatory and antiulcerogenic drugs.

Moreover, the anti-carcinogenic and anti-mutagenic properties of tannins may be related to its antioxidant action, which consists in protecting the cells against damages caused by cellular oxidation, including lipid peroxidation (Oliveria et al., 1991). In fact, the inhibition of super-oxide radicals reported by Chung et al. (1998) was attributed to the incidence of tannins and related compounds.

A relevant aspect to be taken into account when dealing with medicinal plants is the chemical composition variation due to the geographic localization, harvest time, climate conditions, cultivation handling, age of vegetable material, period and storing conditions, among others (Farias, 2003). For example, significant differences in chemical composition was verified in extracts of maté plants with different age of leaves, age of plants, cultivated with diverse fertilisation types and exposed to a variety of light intensity (Esmelindro et al., 2004). Also, Radomski (2004) found that the poly-phenols content was greater in Maytenus ilicifolia cultivated at total sun exposure than at shadow. Nevertheless, there is a lack of studies regarding the environmental effects on the chemical composition of Maytenus ilicifolia.

Another important aspect that should also be considered when dealing with extracts or essential oils in phytotherapy is related to the extraction technique employed. Of course, it is important that the method utilised does not modify the original properties and provides satisfactory yields with the lowest solvent residue. Carbon dioxide has been used as solvent in most cases for supercritical extraction purposes in food and pharmaceutical industries since it is nontoxic, nonflammable, non-explosive, readily available, and has a low critical temperature that avoids degradation of thermo sensitive compounds. The advantages of using near critical carbon dioxide extraction prevail when small raw material amounts and high quality products are processed (Coelho, 1996; Saldaña et al., 2002). Besides, Catchpole et al. (2002) mention that the use of compressed carbon dioxide may be an advantageous alternative for obtaining natural remedies with therapeutic interests.

In this context, the objective of this work is to investigate the chemical composition variation of tannins and the triterpenes friedelin, friedelan-3-ol and friedelan-3-one in 15 native populations of Maytenus ilicifolia. The tannin and triterpene contents were correlated to the macroenvironmental variables average annual temperature, climate, vegetation, geomorphology, latitude and altitude using Pearson's coefficient.

\section{Materials and Methods}

\subsection{Plant samples}

Evaluation was conducted of samples of fifteen natural populations of Maytenus ilicifolia from four Brazilian states: Rio Grande do Sul (Barão de Cotegipe, Canguçu, Erechim, Santana do Livramento, São José, Soledade, Unistalda and Vale Verde), Santa Catarina (Caçador, Lages and São Joaquim), Paraná (Guarapuava, Irati and Mangueirinha) and Mato Grosso do Sul (Ponta Porã). Figure 1 presents the geographic localisation of the sample collections.

In this study, the groups of non-cultivated plants, with natural occurrence in a continuous original forest were considered as natural population. Each population was represented by 30 adult plants, randomly collected to represent all the area occupied by the population and with a minimum distance of $20 \mathrm{~m}$ between plants. Samples were collected during the winter (June and July), and immediately dried at room temperature. The bulked samples were triturated and sieved, collecting 100 to 200 mesh particles. The samples were then stored at room temperature under nitrogen atmosphere prior the extraction.

\subsection{Extraction and quantification of tannins}

For tannins extraction from Maytenus ilicifolia, $100 \mathrm{~mL}$ of bi-distilled water was added to $1 \mathrm{~g}$ of dried leaves and heated with total reflux during 1 hour. The tannin content was determined spectrophotometrically $(\lambda=760 \mathrm{~nm}$ ) using the Folin - Denis (Habiba, 2002) reagent. The concentration was then calculated through a standard curve, prepared with a standard solution of tanic acid (concentration range of 5 to $500 \mathrm{mg} . \mathrm{L}^{-1}$ ). Extraction and quantification were carried out in triplicate.

\subsection{Triterpenes extraction procedure}

In a previous report, the effect of temperature, solvent density, particle size of vegetable material and solvent (carbon dioxide) flow rate on the extraction yield and chemical characteristics of the extracts of Maytenus ilicifolia (Mossi et al., 2004) had been evaluated. In this work, the extractions were performed in a laboratoryscale high-pressure carbon dioxide unit, described in detail by Mossi et al. (2004) and Esmelindro et al. (2004). Basically, the apparatus consists of a $\mathrm{CO}_{2}$ reservoir, two thermostatic baths, a syringe pump (ISCO 


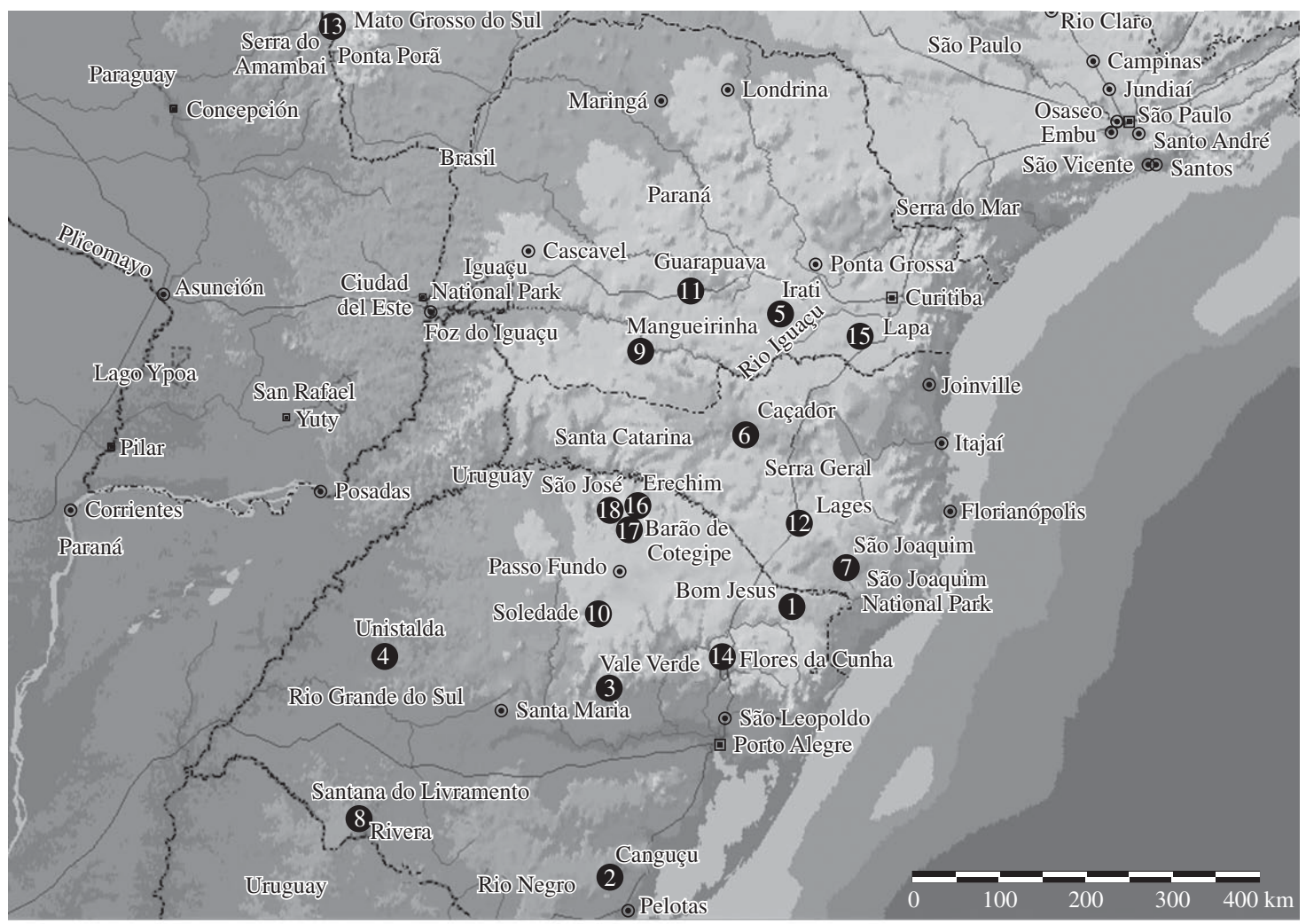

Figure 1. Geographical localization of the Maytenus ilicifolia populations investigated in this work.

500D), a $0.1 \mathrm{dm}^{3}$ jacketed extraction vessel, an absolute pressure transducer (Smar, LD301) equipped with a portable programmer (Smar, HT 201) with a precision of 0.30 bar, a collector vessel with a glass tube, and a cold trap.

Powdered leaves samples ( $25 \mathrm{~g}$ ) were charged into the extraction vessel. The solvent (carbon dioxide, White Martins S.A., $99.9 \%$ in the liquid phase) was pumped into the bed, which was supported by two 300 mesh wire disks at both ends, and was kept in contact with the herbaceous matrix for at least one hour to allow the system stabilization. Afterwards, the essential oil was collected opening the micrometering valve and the $\mathrm{CO}_{2}$ mass flow, kept constant at around $2 \mathrm{~g} / \mathrm{min}$, was accounted for in the pump recordings. At the end of the process, the extract was weighed and transferred to an appropriate vessel.

Based on the work of Mossi et al. (2004), the following extraction condition was adopted: $35^{\circ} \mathrm{C}, 175$ atm and 90 minutes extraction. The extracts obtained were combined into a unique fraction and then stored under refrigeration in nitrogen atmosphere prior to analysis. The extractions were carried out in triplicate, leading to an average extraction yield of $1.1 \mathrm{wt} .(\%)$. The yield is defined here as the weight percentage of the oil extracted with respect to the initial charge of the raw material in the extractor.

\subsection{Extract analysis}

The extracts were analysed through GC/MSD equipment (Shimadzu QP5050A), using a capillary column DB5 $(30 \mathrm{~m} \times 0.25 \mathrm{~mm} \times 0.25 \mu \mathrm{m})$. Column temperature was programmed as follows: $55^{\circ} \mathrm{C} / 3$ minutes, $3{ }^{\circ} \mathrm{C}$ per min to $260{ }^{\circ} \mathrm{C}, 2.5{ }^{\circ} \mathrm{C}$ per min to $310{ }^{\circ} \mathrm{C} / 10$ minutes. Helium was the carrier gas at a flow rate of $1.0 \mathrm{~mL} / \mathrm{min}$, split mode (split ratio $1: 10$ ), at $310^{\circ} \mathrm{C}$ interface temperature. The sample ( $1 \mu \mathrm{L}$ of $40000 \mathrm{mg}$. $\mathrm{L}^{-1}$ in $\mathrm{CH}_{2} \mathrm{Cl}_{2}$ ) components were identified by matching their mass spectra with those of the Wiley library database and by comparison of retention times with standards. An internal standard (biphenyl $100 \mathrm{mg} . \mathrm{L}^{-1}$ ) was added to all samples and the content of each compound was calculated by the ratio between the peak area of the compound by the peak area of the internal standard. Friedelan-3-ol, friedelin and friedelan-3-one were quantified through the injection of authentic standards (Sigma-Aldrich Co). Three replicate injections were performed for each sample.

\subsection{Environmental characteristics}

In this work, the effects of the average annual temperature, climate, vegetation, geomorphology, latitude and altitude on the concentration of triterpenes (friedelan-3-ol, friedelan-3-one and friedelin) and tannins present in the extracts of Maytenus ilicifolia were 
investigated. Values of the environmental parameters were determined from the IBGE (Instituto Brasileiro de Geografia e Estatística) database. The abbreviations $\mathrm{Cfa}, \mathrm{Cfb}$ and Aw refer to the Koeppen climate classification and correspond to subtropical, humid temperate and tropical climates, respectively. Table 1 summarises the environmental characteristics of the populations investigated in this work.

\subsection{Statistical analysis}

The statistical analysis was accomplished with the ANOVA test coupled with the Tukey test at a 95\% confidence level. Correlation of environmental variables with chemical composition was attempted using the Pearson test $(p<0.05)$. Populations were grouped based on the total content of triterpenes and tannins and were analyzed through cluster analysis. All the statistical analysis was performed with the appropriate procedures of the computer package Statistica ${ }^{\circledR}$ 5.5.

\section{Results and Discussion}

Table 2 presents the results of the statistical analysis (ANOVA and Tukey test, $\mathrm{p}<0.05$ ) of the mean concentration values of the triterpenes fridelan-3-one, friedelan-3-ol, friedelin and tannins in the 15 populations of Maytenus ilicifolia investigated. As can be seen from this table, the concentration of friedelan-3-ol is much greater than the other triterpenes except for the population of Santana do Livramento. The concentration of friedelan-3-one, friedelan-3-ol and friedelin corresponds, re- spectively, to approximately $5 \%, 59 \%$ and $36 \%$ of the whole triterpenes concentration for all the populations analyzed.

With regard to the total concentration of triterpenes evaluated, the greatest concentrations were found in the populations of Erechim, Barão de Cotegipe, São José and Lages. It can be observed from Table 2 that the highest and smallest statistically significant concentrations of total triterpenes were verified to occur in the populations of Erechim/Barão de Cotegipe and Santana do Livramento, respectively, while other populations show intermediate concentration values and do not differ among them on the basis of the statistical confidence level adopted. The population of Santana do Livramento, geographically situated in the extreme south regarding species occurrence in Brazil, may be located in a marginal area for this species, since Maytenus ilicifolia is not found in Uruguay, which explains the lowest triterpenes production. This means that micro-environmental variables and/or genetic characteristics of these populations may be affecting the production of triterpenes.

Figure 2 presents the grouping analysis (UPGMA algorithm) for the triterpenes concentration for all populations. It can be noted two groups, Erechim and Barão de Cotegipe, which clearly stand out from the others. From the results shown in Table 3, one can see that, according to Pearson's coefficient ( $\mathrm{p}<0.05)$, there is no correlation between the total concentration of triterpenes and environmental variables studied.

Table 1. Environmental characteristics of the fifteen populations of Maytenus ilicifolia investigated.

\begin{tabular}{|c|c|c|c|c|c|c|}
\hline Population & Vegetation & Climate* & $\begin{array}{l}\text { AAT } \\
\left({ }^{\circ} \mathbf{C}\right)\end{array}$ & $\begin{array}{l}\text { Altitude } \\
\text { (m) }\end{array}$ & $\begin{array}{c}\text { Latitude } \\
\text { (Southern) }\end{array}$ & Geomorphology \\
\hline $\begin{array}{l}\text { Barão de } \\
\text { Cotegipe }\end{array}$ & Mixed Ombrophilous Forest & Cfa & $16-18$ & $600-900$ & $27^{\circ} 37^{\prime} 15^{\prime \prime}$ & Magmatic Rocks \\
\hline Caçador & Mixed Ombrophilous Forest & $\mathrm{Cfb}$ & $13-15$ & $900-1200$ & $26^{\circ} 47^{\prime} 51^{\prime \prime}$ & Magmatic Rocks \\
\hline Canguçu & Seasonal Tropical Forest & Cfa & $19-21$ & $300-600$ & $31^{\circ} 23^{\prime} 42^{\prime \prime}$ & Metamorphic Rocks \\
\hline Erechim & Mixed Ombrophilous Forest & $\mathrm{Cfa}$ & $16-18$ & $600-900$ & $27^{\circ} 37^{\prime} 54^{\prime \prime}$ & Magmatic Rocks \\
\hline Guarapuava & Mixed Ombrophilous Forest & $\mathrm{Cfb}$ & $16-18$ & $900-1200$ & $25^{\circ} 23^{\prime} 26^{\prime \prime}$ & Magmatic Rocks \\
\hline Irati & Mixed Ombrophilous Forest & $\mathrm{Cfb}$ & $16-18$ & $600-900$ & $25^{\circ} 27^{\prime} 56^{\prime \prime}$ & Sedimentary Rocks \\
\hline Lages & Steppe & $\mathrm{Cfb}$ & $13-15$ & $900-1200$ & $27^{\circ} 48^{\prime} 58^{\prime \prime}$ & Magmatic Rocks \\
\hline Mangueirinha & Mixed Ombrophilous Forest & $\mathrm{Cfa}$ & $16-18$ & $900-1200$ & $25^{\circ} 56^{\prime} 09^{\prime \prime}$ & Magmatic Rocks \\
\hline Ponta Porã & Steppe & Aw & $22-24$ & $600-900$ & $22^{\circ} 32^{\prime} 10^{\prime \prime}$ & Magmatic Rocks \\
\hline $\begin{array}{l}\text { Santana do } \\
\text { Livramento }\end{array}$ & Steppe & $\mathrm{Cfa}$ & $19-21$ & & $30^{\circ} 53^{\prime} 27^{\prime \prime}$ & Sedimentary Roks \\
\hline São Joaquim & Steppe & $\mathrm{Cfb}$ & $13-15$ & $900-1200$ & $28^{\circ} 17^{\prime} 38^{\prime \prime}$ & Magmatic Rocks \\
\hline São José & Mixed Ombrophilous Forest & Cfa & $16-18$ & $600-900$ & $27^{\circ} 37^{\prime} 20^{\prime \prime}$ & Magmatic Rocks \\
\hline Soledade & Steppe & $\mathrm{Cfa}$ & $16-18$ & $600-900$ & $28^{\circ} 49^{\prime} 06^{\prime \prime}$ & Magmatic Rocks \\
\hline Unistalda & Steppe & Cfa & $19-21$ & $300-600$ & $29^{\circ} 02^{\prime} 50^{\prime \prime}$ & Sedimentary Rocks \\
\hline Vale verde & Seasonal Tropical Forest & $\mathrm{Cfa}$ & $19-21$ & $0-300$ & $29^{\circ} 47^{\prime} 13^{\prime \prime}$ & Sedimentary Rocks \\
\hline
\end{tabular}

* Cfa, $\mathrm{Cfb}$ and Aw denote, respectively, subtropical, humid temperate and tropical climates (climate classification according to Koeppen). AAT means the average annual temperature. 
Table 2. Statistical analysis (ANOVA and Tukey test) of the concentration (mg. $\mathrm{g}^{-1}$ ) of triterpenes and tannins in the fifteen populations of Maytenus ilicifolia investigated.

\begin{tabular}{lccccc}
\hline \multicolumn{1}{c}{ Population } & Friedelan-3-one & Friedelan-3-ol & Friedelin & Total triterpenes & Tannins \\
\hline Barão de Cotegipe & $0.44^{\mathrm{c}}$ & $12.18^{\mathrm{ab}}$ & $9.48^{\mathrm{ab}}$ & $22.10^{\mathrm{a}}$ & $95.23^{\mathrm{e}}$ \\
Caçador & $0.61^{\mathrm{bc}}$ & $4.98^{\mathrm{b}}$ & $3.75^{\mathrm{bc}}$ & $9.34^{\mathrm{b}}$ & $74.18^{\mathrm{f}}$ \\
Canguçu & $0.38^{\mathrm{c}}$ & $7.09^{\mathrm{b}}$ & $4.29^{\mathrm{bc}}$ & $11.76^{\mathrm{b}}$ & $199.87^{\mathrm{b}}$ \\
Erechim & $1.70^{\mathrm{a}}$ & $16.41^{\mathrm{a}}$ & $10.45^{\mathrm{ab}}$ & $28.56^{\mathrm{a}}$ & $117.78^{\mathrm{cd}}$ \\
Guarapuava & $0.83^{\mathrm{bc}}$ & $7.92^{\mathrm{ab}}$ & $2.61^{\mathrm{c}}$ & $11.36^{\mathrm{b}}$ & $139.02^{\mathrm{c}}$ \\
Irati & $0.63^{\mathrm{bc}}$ & $9.37^{\mathrm{ab}}$ & $5.56^{\mathrm{abc}}$ & $15.56^{\mathrm{b}}$ & $106.47^{\mathrm{d}}$ \\
Lages & $0.98^{\mathrm{ab}}$ & $12.27^{\mathrm{ab}}$ & $7.87^{\mathrm{abc}}$ & $21.12^{\mathrm{ab}}$ & $84.97^{\mathrm{ef}}$ \\
Mangueirinha & $0.39^{\mathrm{c}}$ & $5.40^{\mathrm{b}}$ & $4.34^{\mathrm{bc}}$ & $10.13^{\mathrm{b}}$ & $136.14^{\mathrm{c}}$ \\
Ponta Porã & $0.48^{\mathrm{bc}}$ & $9.38^{\mathrm{ab}}$ & $6.01^{\mathrm{abc}}$ & $15.87^{\mathrm{b}}$ & $291.96^{\mathrm{a}}$ \\
Santana do & $0.54^{\mathrm{bc}}$ & $3.52^{\mathrm{c}}$ & $4.61^{\mathrm{bc}}$ & $8.67^{\mathrm{c}}$ & $128.56^{\mathrm{c}}$ \\
Livramento & & & & $108.17^{\mathrm{d}}$ \\
São Joaquim & $0.73^{\mathrm{bc}}$ & $5.93^{\mathrm{b}}$ & $3.04^{\mathrm{c}}$ & $9.70^{\mathrm{b}}$ & $99.02^{\mathrm{e}}$ \\
São José & $0.50^{\mathrm{bc}}$ & $11.06^{\mathrm{ab}}$ & $7.36^{\mathrm{abc}}$ & $18.92^{\mathrm{ab}}$ & $92.22^{\mathrm{e}}$ \\
Soledade & $1.34^{\mathrm{ab}}$ & $8.68^{\mathrm{ab}}$ & $4.20^{\mathrm{bc}}$ & $14.22^{\mathrm{b}}$ & $110.39^{\mathrm{d}}$ \\
Unistalda & $0.63^{\mathrm{bc}}$ & $7.24^{\mathrm{ab}}$ & $2.76^{\mathrm{c}}$ & $10.63^{\mathrm{b}}$ & $12.28^{\mathrm{b}}$ \\
Vale Verde & $0.94^{\mathrm{abc}}$ & $7.39^{\mathrm{ab}}$ & $3.95^{\mathrm{abc}}$ & $107.91^{\mathrm{d}}$ \\
\hline
\end{tabular}

a,b,c,d,e,fdifferent letters among the populations mean significant difference at $95 \%$ of confidence level $(\mathrm{p}<0.05)$ (Tukey test).

Euclidean distances

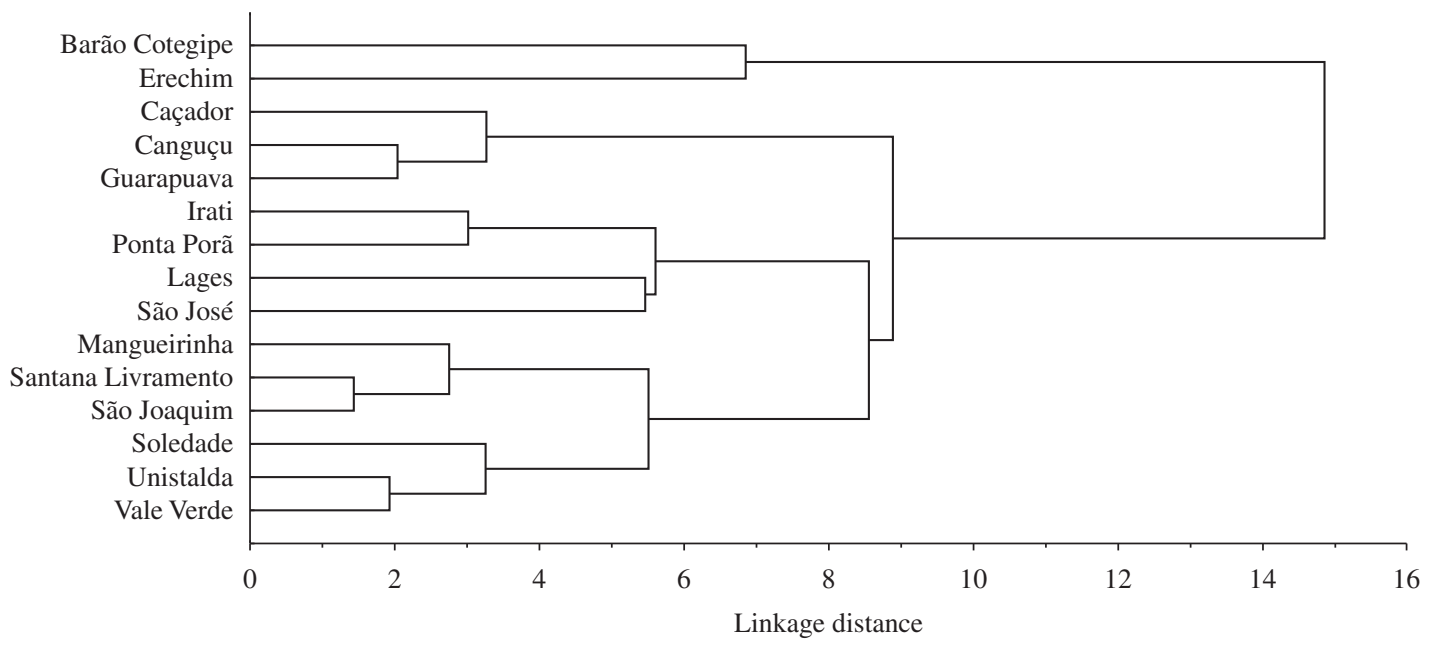

Figure 2. Hierarchical cluster analysis (UPGMA algorithm) dendrogram of 15 populations of Maytenus ilicifolia based on mean Euclidian distances calculated by computing the concentration of triterpenes.

Table 3. Pearson's correlation $(\mathrm{p}<0.05)$ between environmental variables and tannin and triterpene concentration.

\begin{tabular}{lcccccc}
\hline Compounds & AAT & Climate & Vegetation & Latitude & Altitude & Geomorphology \\
\hline Tannins & $0.74 *$ & $0.62^{*}$ & 0.24 & 0.31 & 0.15 & 0.27 \\
Triterpenes & -0.24 & -0.10 & -0.27 & -0.08 & -0.05 & -0.30 \\
\hline
\end{tabular}

*Correlation coefficient statistically significant at $\mathrm{p}<0.05$.

Results for tannin concentration presented in Table 2 demonstrate the occurrence of significant variation in the populations investigated. The populations of Ponta Porã in Mato Grosso do Sul state and Caçador in Santa
Catarina presented, respectively, the highest (292 $\mathrm{mg} \cdot \mathrm{g}^{-1}$ ) and slowest $\left(74.2 \mathrm{mg} \cdot \mathrm{g}^{-1}\right)$ concentration values found. Figure 3 shows that the grouping analysis reveals the existence of four distinct groups: the first one is formed by 


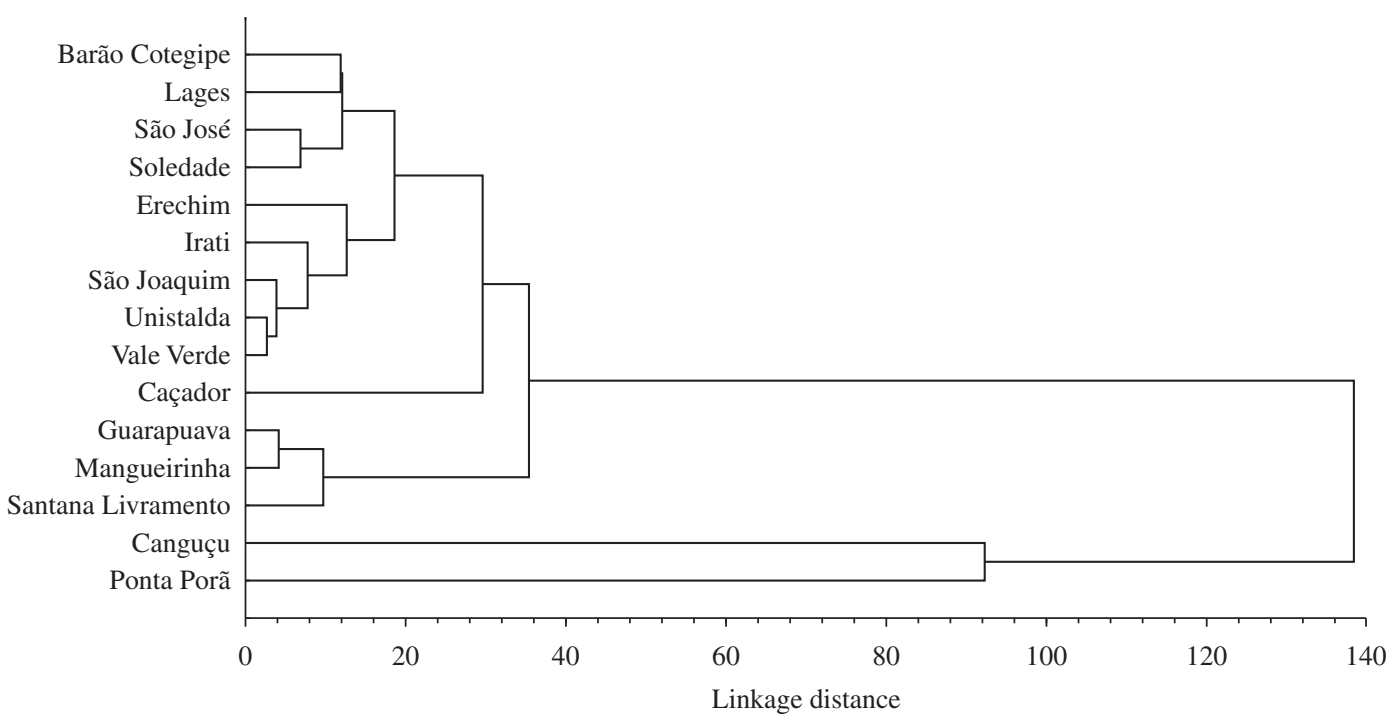

Figure 3. Hierarchical cluster analysis (UPGMA algorithm) dendrogram of 15 populations of Maytenus ilicifolia based on mean Euclidian distances calculated by computing the concentration of tannins.

the population of Ponta Porã and Canguçu, the second by Santana do Livramento, Mangueirinha and Guarapuava, the third group by Caçador and the last one corresponding to all other populations.

With regard to the effect of environmental parameters on the chemical composition of medicinal and aromatic plants, Esmelindro et al. (2004) found that some cultivation parameters may have a pronounced effect on the chemical composition of maté, especially for methylxanthines, vitamin E, phytol, stigmasterol and squalene. Rachval et al. (2002), in studying the effect of sunlight on chemical composition of maté, verified that greater tannin concentrations were found in plants subject to higher sun exposure.

Specifically dealing with Maytenus ilicifolia, Radomski (2004) found higher concentrations of phenolic compounds and density of Maytenus ilicifolia leaves from plants cultivated with direct sun exposure compared to those grown in controlled light and environmental conditions. Pereira et al. (1995) reported that the type and amount of fertilizer do not lead to an enhancement of friedelan-3-ol, friedelin and polyphenol content in Maytenus aquifolia.

The great variation of tannin concentration found in the populations investigated, together with the results presented in Figure 3, suggest the existence of a correlation between environmental parameters and tannin concentration in Maytenus ilicifolia. As shown in Table 3, results from Pearson's correlation $(\mathrm{p}<0.05)$ reveal that climate $(\mathrm{R}=0.62)$ and average annual temperature $(R=0.74)$ have a significant effect on tannin concentration whereas the other variables did not present a significant effect. The low correlation values between the tannin concentration and variables studied implies that, as in the case of triterpene concentration, microenvironmental parameters (microclimate, soil conditions, sunlight level) and genetic factors may also exert an influence on tannin production.

From the Pearson correlation between average annual temperature and tannin concentration, one can see that the higher the temperature, the greater the tannin concentration. The populations of Ponta Porã (AAT of $23{ }^{\circ} \mathrm{C}$ ) presented the greatest concentration of tannins. Another population that should be mentioned is Canguçu (AAT of $21^{\circ} \mathrm{C}$ in near sea area) due to the high content of tannins found. Note also from Table 2 that lower values of tannin concentration were found in the populations of Caçador, Lages and São Joaquim, which according to Table 1 have low AAT. These results are in complete agreement with those of Rachval et al. (2002), who reported that plants cultivated in complete sun exposure produce tannins as a defense mechanism against ultraviolet ray incidence. Results obtained in this work may be of relevance, if we take into account the appropriate cultivation of Maytenus ilicifolia towards increasing the production of tannins and specific triterpene compounds such as friedelan-3-one, friedelan-3-ol and friedelin for possible pharmaceutical applications.

Acknowledgements - The authors would like to express their gratitude to CNPq, FAPERGS and SCT-RS for the financial support for this research.

\section{References}

CATCHPOLE, OJ., PERRY, NB., SILVA, BMT., GREY, JB. and SMALLFIELD, BM., 2002. Supercritical extraction of herbs I: 
Saw Palmetto, St John's Wort, Kava Root and Echinacea. The Journal of Supercritical Fluids, vol. 22, no. 2, p. 129-138.

CHUNG, KT., WONG, TY., WEI, CY., HUANG, YWY. and LIN, YY., 1998. Tannins and human health: a review. Critical Reviews in Food Science and Nutrition, vol. 38, no. 6, p. 421-464.

COELHO, LAF., 1996. Extração supercrítica de óleo essencial de Rosmarinus officinalis: dados experimentais, modelagem do processo e predição da solubilidade. Florianópolis: Universidade Federal de Santa Catarina. 189p. Dissertação de Mestrado.

ESMELINDRO, AA., SANTOS, JG., MOSSI, A., JACQUES, RA. and DARIVA, C., 2004. Influence of agronomic variables on the composition of mate tea leaves (Ilex paraguariensis) extracts obtained from $\mathrm{CO}_{2}$ extraction at $30^{\circ} \mathrm{C}$ and 175 bar. Journal of Agricultural and Food Chemistry, vol. 52, no. 7, p. 1990-1995.

FARIAS, MR. 2003. Avaliação da qualidade de matérias-primas vegetais. In SIMÕES, COM., SCHENKEL, EP., GOSMANN, G., MELO, JCP., MENTZ, LA. and PETROVICK, PR. (Orgs.). Farmacognosia da planta ao medicamento. 5 ed. Porto Alegre; Florianópolis: Editora da UFRGS; UFSC. p. 263-288.

HABIBA, RA., 2002. Changes in anti-nutrients, protein solubility, digestibility, and $\mathrm{HCl}$ extractability of ash and phosphorus in vegetable peas as affected by cooking methods. Food Chemistry, vol. 77, no. 2, p. 187-192.

JORGE, RM., LEITE, JPV., OLIVEIRA, AB. and TAGLIATI, CA., 2004. Evaluation of anticonceptive, anti-inflammatory and antiulcerogenic activities of Maytenus ilicifolia. Journal of Ethnopharmacology, vol. 94, no. 1, p. 93-100.

MOSSI, AJ., CANSIAN, RL., CARVALHO, AZ., DARIVA, C., OLIVEIRA, JV., MAZUTTI, M., NASCIMENTO FILHO, I. and ECHEVERRIGARAY, S., 2004. Extraction and characterization of volatile compounds in Maytenus ilicifolia Mart. ex Reiss, using high-pressure $\mathrm{CO}_{2}$. Fitoterapia, vol. 75, no. 2, p. 168-178.

OHSAKI, A., IMAI, Y., NARUSE, M., AYABE, S., KOMIYAMA, K. and TAKSHIMA, J., 2004. Four new triterpenoids from Maytenus ilicifolia. Journal of Natural Products, vol. 67, no. 3, p. 469-471.

OLIVEIRA, MG., MONTEIRO, MG., MACAÚBAS, C., BARBOSA, VP. and CARLINI, EA., 1991. Pharmacologic and toxicologic effects of two Maytenus species in laboratory animals. Journal of Ethnopharmacology, vol. 34, no. 1, p. 29-41.

PEREIRA, AMS., MENEZES, A., PEREIRA, PS., CERDEIRA, RMM., FRANÇA, SC., VILEGAS, JHY., CORDEIRO, PJM. and LANÇAS, FM., 1995. Effect of fertilization on morphologic characteristics and secondary metabolites of Maytenus aquifolium Mart. Journal of Herbs, Spices \& Medicinal Plants, vol. 3 , no. 2, p. 43-50.

QUEIROGA, CL., SILVA, GF., DIAS, PC., POSSENTI, A. and CARVALHO, JE., 2000. Evaluation of the antiulcerogenic activity of friedelan-3 $\beta$-ol and friedelin isolated from Maytenus ilicifolia (Celastraceae). Journal of Ethnopharmacology, vol. 72 , no. 2, p. 465-468.

RACHVAL, MFG., COELHO, GC., DEDECECK, RA., CURCIO, GR. and SCHENKEL, EP., 2002. Efeito da luminosidade sobre a produção de massa foliar e teores de macronutrientes, fenóis totais, cafeína e teobromina em folhas de Erva Mate. Circular Técnica Embrapa Florestas, vol. 81, p. 5.

RADOMSKI, MI., WISNIEWSKI, C., CURCIO, GR., RACHWAL, MG. and SANTOS, CAM., 2004. Caracterização de ambientes de ocorrência natural e sua influência sobre o peso específico e o teor de polifenóis totais de folhas de espinheirasanta (Maytenus ilicifolia Mart.). Brazilian Journal of Medicinal Plants, vol. 6, no. 2, p. 36-43.

SALDAÑA, MDA., ZETZL, C., MOHAMED, R. and BRUNNER, G., 2002. Extraction of methylxanthines from guaraná seeds, maté leaves and cocoa beans using supercritical carbon dioxide and ethanol. Journal of Agricultural and Food Chemistry, vol. 50, no. 17, p. 4820-4826.

SOUZA-FORMIGORI, ML. and OLIVEIRA, MGM., 1991. Antiulcerogenic effects of two Maytenus species in laboratory animals. Journal of Ethnopharmacology, vol. 34, no. 1, p. 21-27.

TAHIR, AEL., SATTI, GMH. and KHALID, SA., 1999. Antiplasmodial activity of selected Sudanese medicinal plants with emphasis on Maytenus senegalensis (Lam.) Exell. Journal of Ethnopharmacology, vol. 64, no. 3, p. 227-233.

VILEGAS, JHY., LANÇAS, FM. and ANTONIOSI FILHO, NR., 1995. High temperature capillary GC analysis of phytopreparations of espinheira-santa (Maytenus ilicifolia and Maytenus aquifolium), a Brazilian antiulcer plant. Chromatographia, vol. 40, no. 5-6, p. 341-344. 
